\title{
Characterization and quantification of the cholesterol oxidation product fraction of the intramuscular fat from pork loin (fresh and marinated) with different irradiation and packaging during storage
}

\author{
I. García-Márquez ${ }^{\mathrm{b}}$, M. Narváez-Rivas ${ }^{\mathrm{a}}$, E. Gallardo ${ }^{\mathrm{a}}$, J.A. Ordoñez ${ }^{\mathrm{b}}$ and M. León-Camacho ${ }^{\mathrm{a}, \bowtie}$ \\ ${ }^{a}$ Lipid Characterization and Quality Department. Instituto de la Grasa (C.S.I.C.). Spain \\ ${ }^{\mathrm{b}}$ Department of Nutrition, Bromatology and Food Technology Faculty of Veterinary, \\ University Complutense, Avda. Puerta de Hierro, S/N, E-28040 Madrid, Spain \\ ${ }^{\square}$ Corresponding author: mleon@cica.es
}

Submitted: 24 April 2014; Accepted: 9 June 2014

\begin{abstract}
SUMMARY: A study of the effect of E-beam (1 and $2 \mathrm{kGy}$ ) on the cholesterol oxidation product (COP) composition of fresh and marinated pork loin stored at 4 and $8{ }^{\circ} \mathrm{C}$ under different atmospheres (air, vacuum and carbon dioxide enriched ) has been carried out for the first time. The combined statistical treatment of the distinct variables showed that minor differences were found in some cholesterol oxidation products of fresh loin due to storage temperature, packaging method and storage time. No effect of irradiation (up to $2 \mathrm{KGy}$ ) on the COP amount was found, concluding that E-beam can be a useful tool to extend the shelf-life of fresh and marinated loin without changes in the COP fraction.
\end{abstract}

KEYWORDS: Cholesterol oxidation products; E-beam irradiation; Fresh loin; Intramuscular fat; Marinated loin; Packaging

RESUMEN: Caracterización y cuantificación de los productos de oxidación del colesterol de la grasa intramuscular del lomo de cerdo (fresco y adobado) con diferentes irradiaciones y empaquetados durante el almacenamiento. Se ha realizado un estudio sobre el efecto de la radiación de electrones (E-beam) (1 y 2 kGy) sobre los compuestos de oxidación del colesterol (COPs) del lomo de cerdo almacenado a 4 y $8^{\circ} \mathrm{C}$ bajo diferentes atmósferas (aire, vacío y dióxido de carbono). Este tipo de estudio ha sido llevado a cabo por primera vez en este tipo de muestras. El tratamiento estadístico combinado de distintas variables muestra que se producen cambios menores en algunos COPs en el lomo fresco debido a la temperatura de almacenamiento al método de empaquetado y al tiempo de almacenamiento. No hubo efecto de la dosis de radiación (hasta $2 \mathrm{KGy}$ ) en los COPs, por lo que la radiación E-beam puede ser una herramienta útil para prolongar la vida útil del lomo fresco y adobado sin producir cambios en la composición de los COPs.

PALABRAS CLAVE: Compuestos de oxidación del colesterol; Grasa intramuscular; Lomo adobado; Lomo fresco; Radiación E-beam; Sistema de empaquetado

Citation/Cómo citar este artículo: García-Márquez I, Narváez-Rivas M, Gallardo E, Ordoñez J.A, León-Camacho M. 2014. Characterization and quantification of the cholesterol oxidation product fraction of the intramuscular fat from pork loin (fresh and marinated) with different irradiation and packaging during storage. Grasas Aceites 65 (4): e045. doi: http://dx.doi.org/10.3989/gya.0465141.

Copyright: (C) 2014 CSIC. This is an open-access article distributed under the terms of the Creative Commons Attribution-Non Commercial (by-nc) Spain 3.0 Licence.

\section{INTRODUCTION}

Pork production has a great importance in human nutrition because it provides more than $39 \%$ of the global production of meat for human consumption, equivalent to $15.3 \mathrm{~kg}$ of meat per person per year (FAOSTAT 2004). The global pig population in 2002 was 956 million heads with an upward trend, due mainly to consumption in China (FAOSTAT 2004). The distribution of the census 
is very heterogeneous, and is concentrated mostly in Asia (60\%), especially in China (47\% of world census), followed by Europe (21\%), U.S. (9\%) and Brazil (4\%). In Spain, the farmed pig is the number one breed in volumes of animals and tons of meat produced. This country is the 2nd largest European producer, its production was 3.5 million tons in 2008 (MAPA 2006).

Cholesterol is a steroid of animal origin that has numerous metabolic functions. Although cholesterol is a relatively stable compound, it can be oxidized under harsh conditions, high processing temperatures, like cooking, and during the storage and packaging of products of animal origin (Paniangvait et al., 1995; Penazzi et al., 1995; Dionisi et al., 1998). Cholesterol oxidation reactions give rise to a wide range of secondary products generically called Cholesterol oxidation products (COPs).

The factors contributing to the formation of COPs are as follows: presence of oxygen (free radical oxidation), light (photo-oxidation), and high temperatures (enzymatic oxidation). (Ubhayasekera et al., 2009). Thus, the use of packaging materials capable of avoiding the entrance of air and light, along with the use of proper storage temperature, could delay their formation (Savage et al., 2002; Paniangvait et al., 1995). COPs are considered more harmful than cholesterol and they have been shown to be cytotoxic, atherogenic, mutagenic and carcinogenic (Park et al., 1985, Smith et al., 1980, Kubow et al., 1990; Sevanian et al., 1986; Leonarduzzi et al., 2002).

The mechanism of COP action seems to be related to the bioavailability (Lund et al., 1994) and dietary uptake of cholesterol (Peng et al., 1985). COPs also impair membrane function, perturbing permeability, stability and other properties (Hennig et al., 1987; Guardiola et al., 1996). They contribute to the development of atherosclerosis due to their negative influence on the permeability of blood vessels and the synthesis of prostaglandins along with thrombocite aggregation (Guardiola et al., 1996). So, a high consumption of COPs has an adverse effect on human health.

The most common products of cholesterol oxidation in foods are: $7 \alpha$-hydroxycholesterol, $7 \beta$-hydroxycholesterol, $5 \alpha, 6 \alpha$-epoxycholesterol, $5 \beta$, $6 \beta$-epoxycholesterol, 7-ketocholesterol and cholestanetriol (Derewiaka et al., 2010).

Currently, there is a good method for sanitizing food which could be accepted in food safety. This is the use of E-beam radiation. Irradiation is applied to improve the microbial safety of meat, but it can also be the precursor to the formation of COPs, because it increases fatty acid oxidation in the meat system. It has been found that the amount of cholesterol oxidation depends on the applied dose (Lebovics et al., 1992). The packaging and storage conditions after the irradiation treatment are also important (Ahn et al., 1998). In this way, the quality of the meat may be more or less affected, depending on dose, temperature and atmosphere during the treatment and storage conditions (Ahn et al., 1998).

At the present time in the European Union, "dried herbs, spices and vegetable seasonings" are the only food ingredients that can be treated with ionizing radiation, as established by the Directives 1999/2/EC (EC, 1999a) and 1999/3/EC (EC, 1999b). The treatment with E-beam radiation of meat and meat products has not been authorized, except for some meats in several countries, such as chicken meat in The Netherlands, poultry in France and The United Kingdom, and the mechanically separated meat of poultry in Belgium and France (EC, 2002). The Food and Drug Administration (FDA) and The U. S. Department of Agriculture (USDA) have approved the treatment of spices, fruits, vegetables, wheat and wheat flour in pork, chicken and red meat (IFT, 1999; Anón., 2000).

The presence of COPs in meat and meat products, coupled with their proven harmful biological activity, has promoted the realization of extensive research to understand the formation mechanism of these compounds and to determine the effect on health from its intake. In several studies, their analysis was done by gas chromatography (GC) and previous purification by solid phase extraction (SPE). Hwang et al., (1993) developed a methodology capable of measuring low concentrations of COPs in irradiated and non-irradiated meat (pork and beef). The aim of the study done by Ubhayasekeraa et al. (2004) was to obtain a method for the purification and enrichment of COPs, using different methods of saponification and transesterification of lipids in tallow. In such study, the analysis of COPs was done using four different methods, in which cold and hot saponification and transesterification were used.

The aim of this work is to investigate the effect of electron-beam irradiation on the oxidation of cholesterol in raw and marinated pork loin with different packaging (García-Márquez et al., 2013a) and storage times.

\section{MATERIALS AND METHODS}

\subsection{Reagents and standards}

Hexane, a fraction from petroleum, Multisolvent TM HPLC ACS grade supplied by Scharlau (Barcelona, Spain) was distilled through a fractionation column. Chloroform, methanol, diethyl ether and potassium hydroxide for analysis grade were provided by Merck (Darmstadt, Germany).

Acetone and pyridine anhydrous for analysis grade were provided by Merck (Darmstadt, Germany). Chlorotrimethylsilane and hexamethyldisilazane were supplied by Fluka (Seelze, Germany) 
and betulin (Sigma Chemical Co., St. Louis, MO, USA) was used as an internal standard. All other materials were analytical grade.

Cholesterol and the standards used for the identification of COPs, cholestane- $5 \alpha-6 \alpha$-epoxide, cholestane- $3 \beta-5 \alpha-6 \beta$-triol, 25-hydroxycholesterol and 5-cholesten-3 $\beta$-ol-7-one, were purchased from Sigma Chemical Co. (St. Louis, MO, USA).

\subsection{Samples and sample treatments}

A total of fifty-four samples of fresh and marinated (prepared with the addition of salts, ascorbic acid, nitrifying, garlic, paprika and others) loin from castrated male white pigs were used. Table 1 shows the treatments applied and the identification code assigned to each one. The lipids were obtained from 10 grams of each sample by extraction with chloroform-methanol (2:1 v/v) according to the procedure described by Folch et al. (1957). The samples were cut up into small pieces and homogenized before extraction with $3 \times 50 \mathrm{~mL}$ of solvent using an agitator, then $100 \mathrm{~mL}$ distilled water was added. The chloroform solution was filtered over anhydrous sodium sulphate, and the samples were extracted with $3 \times 50 \mathrm{~mL}$ of diethyl ether. The extracts were combined with the chloroform solution and then evaporated to dryness in a rotary evaporator at $30{ }^{\circ} \mathrm{C}$ under reduced pressure.

The unsaponifiable fraction was extracted according to the method of Narváez-Rivas et al. (2014). Fat $(0.2 \mathrm{~g})$ was placed in a glass Pyrex tube where $1 \mathrm{~mL}$ of internal standard solution $\left(0.16 \mathrm{mg} \mathrm{mL}^{-1}\right.$ of chloroform) was previously added and evaporated under nitrogen. The mixture was saponified with
$5 \mathrm{~mL}$ of ethanolic potassium hydroxide (2M) that contained $20 \%(\mathrm{v} / \mathrm{v})$ water in an oven with air circulation and heated at $85^{\circ} \mathrm{C}$ for $45 \mathrm{~min}$. After cooling at room temperature, $10 \mathrm{~mL}$ distilled water was added and the solution was transferred to a $50-\mathrm{mL}$ decanting funnel prior to extraction. Then, the mixture was extracted with three $10 \mathrm{~mL}$ portions of diethyl ether. The extracts were combined in another funnel and were washed several times with $10-\mathrm{mL}$ portions of distilled water, until the wash was at a neutral $\mathrm{pH}$. The solution of diethyl ether and COPs was dried over anhydrous sodium sulphate and evaporated to dryness in a rotary evaporator at $30{ }^{\circ} \mathrm{C}$ under reduced pressure.

The COP fraction was separated from the unsaponifiable fraction by means of Solid Phase Extraction (SPE) according to the method previously described (Narváez-Rivas et al., 2014). The complete unsaponifiable fraction was dissolved in approximately $0.5 \mathrm{~mL}$ of hexane/diethyl ether $(75: 25, \mathrm{v} / \mathrm{v})$ and transferred to a silica gel bonded column, Supelclean LC-Si, $6 \mathrm{~mL}$ volume; $500 \mathrm{mg}$ sorbent (Supelco Bellefonte, PA, USA) which was previously conditioned with $10 \mathrm{~mL}$-hexane. The column was washed with $4 \mathrm{~mL}$ n-hexane:diethyl ether $(75: 25 \mathrm{v} / \mathrm{v})$ to remove the compounds with minor polarity, and then, the COPs were eluted with $3 \mathrm{~mL}$-hexane:diethyl ether $(60: 40 \mathrm{v} / \mathrm{v})$ and $4 \mathrm{~mL}$ of acetone: methanol $(60: 40 \mathrm{v} / \mathrm{v})$. Both recovered fractions were combined and evaporated to dryness in a rotary evaporator at $30^{\circ} \mathrm{C}$ under reduced pressure. Trimethylsilyl ether (TMSE) derivatives were prepared by adding $0.15 \mathrm{~mL}$ of Pyridine: Chlorotrimethylsilane: hexamethyldisilazane (9:3:1, $\mathrm{v} / \mathrm{v} / \mathrm{v}$ ) at room temperature for $20 \mathrm{~min}$.

TABLE 1. Analyzed intramuscular fat from pork loin samples

\begin{tabular}{llclcc}
\hline Code & Type & Temperature $\left({ }^{\circ} \mathbf{C}\right)$ & Atmosphere & Radiation $(\mathbf{k g y})$ & Time (days) \\
\hline $1 \mathrm{~F}$ & Fresh & 4 & Air & 0 & 0 \\
$2 \mathrm{~F}$ & Fresh & 4 & Air & 1 & 0 \\
$3 \mathrm{~F}$ & Fresh & 4 & Air & 2 & 0 \\
$4 \mathrm{~F}$ & Fresh & 4 & Vacuum & 0 & 0 \\
$5 \mathrm{~F}$ & Fresh & 4 & Vacuum & 1 & 0 \\
$6 \mathrm{~F}$ & Fresh & 4 & Vacuum & 2 & 0 \\
$7 \mathrm{~F}$ & Fresh & 4 & MAP & 0 & 0 \\
$8 \mathrm{~F}$ & Fresh & 4 & MAP & 1 & 0 \\
$9 \mathrm{~F}$ & Fresh & 4 & MAP & 2 & 0 \\
$10 \mathrm{~F}$ & Fresh & 4 & Air & 0 & 10 \\
$11 \mathrm{~F}$ & Fresh & 4 & Air & 1 & 10 \\
$12 \mathrm{~F}$ & Fresh & 4 & Air & 2 & 10 \\
$13 \mathrm{~F}$ & Fresh & 4 & Vacuum & 0 & 10
\end{tabular}


4 • I. García-Márquez, M. Narváez-Rivas, E. Gallardo, J.A. Ordoñez and M. León-Camacho

TABle 1. (Continued)

\begin{tabular}{|c|c|c|c|c|c|}
\hline Code & Type & Temperature $\left({ }^{\circ} \mathrm{C}\right)$ & Atmosphere & Radiation (kGy) & Time (days) \\
\hline $14 \mathrm{~F}$ & Fresh & 4 & Vacuum & 1 & 10 \\
\hline $15 \mathrm{~F}$ & Fresh & 4 & Vacuum & 2 & 10 \\
\hline $16 \mathrm{~F}$ & Fresh & 4 & MAP & 0 & 10 \\
\hline $17 \mathrm{~F}$ & Fresh & 4 & MAP & 1 & 10 \\
\hline $18 \mathrm{~F}$ & Fresh & 4 & MAP & 2 & 10 \\
\hline $19 \mathrm{~F}$ & Fresh & 8 & Air & 0 & 10 \\
\hline $20 \mathrm{~F}$ & Fresh & 8 & Air & 1 & 10 \\
\hline $21 \mathrm{~F}$ & Fresh & 8 & Air & 2 & 10 \\
\hline $22 \mathrm{~F}$ & Fresh & 8 & Vacuum & 0 & 10 \\
\hline $23 \mathrm{~F}$ & Fresh & 8 & Vacuum & 1 & 10 \\
\hline $24 \mathrm{~F}$ & Fresh & 8 & Vacuum & 2 & 10 \\
\hline $25 \mathrm{~F}$ & Fresh & 8 & MAP & 0 & 10 \\
\hline $26 \mathrm{~F}$ & Fresh & 8 & MAP & 1 & 10 \\
\hline $27 \mathrm{~F}$ & Fresh & 8 & MAP & 2 & 10 \\
\hline $1 \mathrm{M}$ & Marinated & 4 & Air & 0 & 0 \\
\hline $2 \mathrm{M}$ & Marinated & 4 & Air & 1 & 0 \\
\hline $3 \mathrm{M}$ & Marinated & 4 & Air & 2 & 0 \\
\hline $4 \mathrm{M}$ & Marinated & 4 & Vacuum & 0 & 0 \\
\hline $5 \mathrm{M}$ & Marinated & 4 & Vacuum & 1 & 0 \\
\hline $6 \mathrm{M}$ & Marinated & 4 & Vacuum & 2 & 0 \\
\hline $7 \mathrm{M}$ & Marinated & 4 & MAP & 0 & 0 \\
\hline $8 \mathrm{M}$ & Marinated & 4 & MAP & 1 & 0 \\
\hline $9 \mathrm{M}$ & Marinated & 4 & MAP & 2 & 0 \\
\hline $10 \mathrm{M}$ & Marinated & 4 & Air & 0 & 10 \\
\hline $11 \mathrm{M}$ & Marinated & 4 & Air & 1 & 10 \\
\hline $12 \mathrm{M}$ & Marinated & 4 & Air & 2 & 10 \\
\hline $13 \mathrm{M}$ & Marinated & 4 & Vacuum & 0 & 10 \\
\hline $14 \mathrm{M}$ & Marinated & 4 & Vacuum & 1 & 10 \\
\hline $15 \mathrm{M}$ & Marinated & 4 & Vacuum & 2 & 10 \\
\hline $16 \mathrm{M}$ & Marinated & 4 & MAP & 0 & 10 \\
\hline $17 \mathrm{M}$ & Marinated & 4 & MAP & 1 & 10 \\
\hline $18 \mathrm{M}$ & Marinated & 4 & MAP & 2 & 10 \\
\hline $19 \mathrm{M}$ & Marinated & 8 & Air & 0 & 10 \\
\hline $20 \mathrm{M}$ & Marinated & 8 & Air & 1 & 10 \\
\hline $21 \mathrm{M}$ & Marinated & 8 & Air & 2 & 10 \\
\hline $22 \mathrm{M}$ & Marinated & 8 & Vacuum & 0 & 10 \\
\hline $23 \mathrm{M}$ & Marinated & 8 & Vacuum & 1 & 10 \\
\hline $24 \mathrm{M}$ & Marinated & 8 & Vacuum & 2 & 10 \\
\hline $25 \mathrm{M}$ & Marinated & 8 & MAP & 0 & 10 \\
\hline $26 \mathrm{M}$ & Marinated & 8 & MAP & 1 & 10 \\
\hline $27 \mathrm{M}$ & Marinated & 8 & MAP & 2 & 10 \\
\hline
\end{tabular}

Grasas Aceites 65 (4), October-December 2014, e045. ISSN-L: 0017-3495 doi: http://dx.doi.org/10.3989/gya.0465141 


\subsection{COP analysis}

The different COPs were analyzed by GC according to the method previously described (NarváezRivas et al., 2014). The GC system consisted of an Agilent (Palo Alto, CA, USA) 7890A gas chromatograph, equipped with a cold-on column injector and a flame ionization detector; a capillary SPB-5 column (30 $\mathrm{m} \times 0,25 \mathrm{~mm}$ i.d., $0,25 \mu \mathrm{m}$ film thickness, Supelco, Bellefonte, PA, USA) and an Agilent G 4513A automatic injector were used. Hydrogen was used as carrier gas at $10 \mathrm{psi}$ constant head pressure. The programming sequence for the GC oven temperature was as follows: an initial temperature of $90^{\circ} \mathrm{C}$ held for $0.5 \mathrm{~min}$ and increased to $290{ }^{\circ} \mathrm{C}$ at a rate of $30.0^{\circ} \mathrm{C} \cdot \mathrm{min}^{-1}$. Once the column reached $290{ }^{\circ} \mathrm{C}$, the temperature was increased to $300{ }^{\circ} \mathrm{C}$ at a rate of $1.0^{\circ} \mathrm{C} \mathrm{min}^{-1}$ and held for a total running time of $25 \mathrm{~min}$. The injector was operated in the splitless mode at $350{ }^{\circ} \mathrm{C}$ with a purge flow to split vent of $15 \mathrm{~mL} \cdot \mathrm{min}^{-1}$ at $0.5 \mathrm{~min}$. The detector temperature was $360{ }^{\circ} \mathrm{C}$, and air and hydrogen had flow rates of 300 and $30 \mathrm{~mL} \cdot \mathrm{min}^{-1}$ to the detector respectively, which had an auxiliary flow of $30 \mathrm{~mL} \cdot \mathrm{min}^{-1}$ of nitrogen.

In order to identify the COPs, an experiment was conducted using a Varian-CP3800 gas chromatograph coupled to a Saturn 2000 ion trap mass spectrometer (Varian, Palo Alto, CA, USA). The GC was equipped with a CP8400 autosampler. Separation was accomplished on a DB-5MS capillary column (30 m long $\times 0.25 \mathrm{~mm}$ i.d, $0.25 \mu \mathrm{m}$ film thickness; J\&W Scientific, Folsom, CA) with a flow rate of $1.0 \mathrm{~mL} \mathrm{m^{-1 }}$ using ultra high purity hydrogen as the carrier gas. The injector temperature was $350{ }^{\circ} \mathrm{C}$. Splitless injection mode was used with a ratio of $1: 10$ at $0.5 \mathrm{~min}$ and the injection volume was $1 \mu \mathrm{L}$. The programming sequence for the GC oven temperature was the same as for GC-FID. Once the column reached $290{ }^{\circ} \mathrm{C}$, the temperature was increased to $300{ }^{\circ} \mathrm{C}$ at a rate of $1.0^{\circ} \mathrm{C} \cdot \mathrm{min}^{-1}$ and for $7.833 \mathrm{~min}$ for a total running time of $25 \mathrm{~min}$. The MS conditions were as follows: transfer line maintained at $290{ }^{\circ} \mathrm{C}$; electronic ionization mode at an ionization voltage of $70 \mathrm{eV}$; scan rate of $1.0 \mathrm{sec} \mathrm{scan}{ }^{-1} ; \mathrm{m} / \mathrm{z}$ range of $25-550 \mathrm{amu}$ and manifold temperature of $180^{\circ} \mathrm{C}$. The dwell time and inter-channel delay was 0.08 secs and 0.02 secs, and the emission current was $10 \mu \mathrm{A}$. Varian Mass Spectrometry Workstation version 6.30 software was used for data acquisition and processing of the results.

\subsection{Quantitative analysis and statistical treatment}

Seven COPs were identified. The peak area of each COP was used as the analytical signal. The quantification for each different COP was carried out using betulin as internal standard.

The COPs identified were considered as chemical descriptors. A data matrix, whose rows are the samples and whose columns are the variables, was built. Each element of this matrix xij corresponds to the content of COP $\mathrm{j}$ for the sample $\mathrm{i}$. A statistical analysis based on non-parametric techniques was used, including the Kolmogorov-Smirnov-Lilliefors test, which was used to evaluate the normality of each variable included in the study. Since the data distribution was not normal, non-parametric tests were applied. The Kruskal-Wallis test was used to determine significant differences for the variables with three levels. This test is considered as an ANOVA test for one factor. The Mann-Whitney U test was used to determinate the differences between two levels of a same variable. This test is considered similar to a Student t-test for independent sample groups. The calculations were made using the statistical package CSS: STATISTICA from StafsoftTM (Tulsa, OK, USA).

\section{RESULTS AND DISCUSSION}

\subsection{Identification of components}

The peak of COPs identified, the relative retention times (TRR) to betulin, the base peak and the molecular ion for their trimethyl silyl ethers are shown in Table 2. These indicate that there was good separation among the different compounds using this method. The compounds elute between 15 and $25 \mathrm{~min}$. This method is very suitable for the analysis of COPs in these types of samples.

Seven compounds have been identified in the COP fraction of the lipid fraction from fresh and marinated loin. Identification of the peaks was carried out using a GC ion-trap-MS and comparing the spectra to those from the NIST (National Institute of Standards and Technology) and Wiley libraries and verified by standards (as TMSE derivatives).

\subsection{COPs in fresh and marinated loin}

Table 3 shows the mean minimum and maximum values of the COPs analyzed in the loin (as $\mathrm{mg} \cdot \mathrm{Kg}^{-1}$ of fat) corresponding to the fresh and marinated pork. In this table, it can be observed

TABLE 2. COPs identified in the fresh and marinated loin

\begin{tabular}{|c|c|c|c|}
\hline Compound & TRR & Base peak & M+ \\
\hline cholest-5-en-3$\beta, 7 \alpha$-diol & 0.62 & & 546 \\
\hline cholest-5-en-3$\beta, 7 \beta$-diol & 0.70 & & 546 \\
\hline cholestane- $5 \beta, 6 \beta$-epoxide & 0.72 & & 472 \\
\hline cholestane- $5 \alpha, 6 \alpha$-epoxide & 0.75 & 367 & 472 \\
\hline cholestane- $3 \beta, 5 \alpha, 6 \beta$-triol & 0.81 & 456 & 636 \\
\hline cholest-5-en-3 $\beta, 25$-diol & 0.86 & 131 & 546 \\
\hline 5-cholesten-3 $\beta$-ol-7-one & 0.88 & 473 & 472 \\
\hline
\end{tabular}


TABLE 3. Means and ranges for the COPs $\left(\mathrm{mg} \cdot \mathrm{Kg}^{-1}\right.$ of fat) determined in the analyzed loin samples and Mann-Whitney U Test By variable. Type Marked tests are significant at $\mathrm{p}<0.05$

\begin{tabular}{|c|c|c|c|c|}
\hline & Fresh $(n=27)$ & Marinated $(n=27)$ & $\mathbf{U}$ & $\mathbf{Z}$ \\
\hline cholest-5-en-3 $\beta, 7 \alpha$-diol & $228.63(0.00-2100.79)$ & $125.68(0.00-315.55)$ & 304.0000 & -1.04665 \\
\hline cholest-5-en-3 $\beta, 7 \beta$-diol $^{\text {a }}$ & $332.14(61.36-2481.65)$ & $169.72(38.56-879.86)$ & 239.0000 & 2.17115 \\
\hline cholestane- $5 \beta, 6 \beta$-epoxide $^{b}$ & $85.79(0.00-1069.54)$ & $20.75(0.00-119.07)$ & 211.0000 & 2.65555 \\
\hline cholestane- $5 \alpha, 6 \alpha$-epoxide & $191.59(27.45-1225.70)$ & $132.85(27.15-510.64)$ & 360.0000 & -0.07785 \\
\hline cholestane-3 $3,5 \alpha, 6 \beta$-triol & $133.26(0.00-2231.05)$ & $52.01(0.00-316.34)$ & 288.0000 & 1.32345 \\
\hline cholest-5-en-3 $\beta, 25$-diol & $273.14(0.00-2134.20)$ & $9.45(0.00-79.74)$ & 336.5000 & 0.48440 \\
\hline 5-cholesten-3 $\beta$-ol-7-one & $270.08(0.00-3221.27)$ & $114.02(0.00-530.08)$ & 350.5000 & 0.24220 \\
\hline Total & $1241.49(140.38-12330.01)$ & $615.03(182.08-1920.57)$ & 308.0000 & 0.97745 \\
\hline
\end{tabular}

${ }^{\mathrm{a}}$ for $\mathrm{p}<0.05$; ${ }^{\mathrm{b}}$ for $\mathrm{p}<0.01$

that all COPs were detected in both types of samples (fresh and marinated loin).

The most abundant COP was cholest-5-en$3 \beta, 7 \beta$-diol, with average values of $332.14 \mathrm{mg} \cdot \mathrm{Kg}^{-1}$ in fresh loin and $169.72 \mathrm{mg} \cdot \mathrm{Kg}^{-1}$ in marinated loin. The other major COP was cholest-5-en-3ß,25-diol in fresh loin with an average value of $273.14 \mathrm{mg} \cdot \mathrm{Kg}^{-1}$ and cholestane-5 $\alpha, 6 \alpha$-epoxide in marinated loin with an average value of $132.85 \mathrm{mg} \cdot \mathrm{Kg}^{-1}$. The total amount of COPs in fresh loin was much higher $\left(1241.49 \mathrm{mg} \cdot \mathrm{Kg}^{-1}\right)$ than those found in marinated loin $\left(615.03 \mathrm{mg} \cdot \mathrm{Kg}^{-1}\right)$. In addition, the amounts of every COP were higher in fresh than in marinated loin, but there is only a significant increase in two of them: cholest-5-en-3 $\beta, 7 \beta$-diol $(p<0.05)$ and cholestane$5 \beta, 6 \beta$-epoxide $(\mathrm{p}<0.01)$. This protective effect was also observed when some antioxidants, like vitamin $\mathrm{C}$, vitamin $\mathrm{E}, \mathrm{BHA}$ and trolox were used in marinated pork (Lee et al., 2008). The addition of onion and garlic caused a decrease in 7-ketocholesterol and 7-hydroxycholesterol concentrations in pork meat (Janoszca, 2010). The Mann-Whitney U test was performed to determine significant differences between the two types of loin. The statistical parameter U was obtained for each compound and the respective $\mathrm{Z}$-values were calculated for comparison with the $\mathrm{z}$-value in the normalized standard distribution for $95 \%$ confidence $(z=1.96)$. The results of this test are also shown in table 3. It can be observed that the obtained z-values were higher than the critical one for cholest-5-en-3 $3,7 \beta$-diol and cholestane-5 $5,6 \beta$ epoxide, which showed the greatest differences with z-values higher than the critical one (2.17 and 2.66 respectively). The other COPs presented z-values bellow 1.3 (in absolute value), lower than the critical one.

According to the results obtained for the different COPs, the different packaging systems of nonirradiated and irradiated pork loin were treated separately in fresh and marinated loin, as was done for phospholipids (García-Márquez et al., 2013a) and volatile compounds (García-Márquez et al., 2013b) in previous works.

\subsection{Effect of different treatment and storage conditions}

The end of the shelf-life of samples was established when the microbial load reached the value of $107 \mathrm{cfu} / \mathrm{g}$ (Cabeza et al., 2007). Accordingly, the shelf-life of both fresh and marinated loin stored under the selected conditions will be different according to the strength of the method of microbiota inhibition. However, the statistical analysis showed that these differences did not affect to the integrity of most COPs. The normality of the variables in the comparison groups was studied by means of the Kolmogorov - Smirnov-Lilliefors test. In light of the results of this test, a non parametric test such as the Kruskal-Wallis and Mann-Whitney $\mathrm{U}$ test were used for all between-group comparisons.

In order to find out significant differences between different COPs for the two different storage times used ( 0 and 10 days) and both types of samples, a Mann-Whitney U test was performed. The statistical parameter $U$ was obtained for each compound and the respective z-values were calculated for comparison with the z-value in the normalized standard distribution for $95 \%$ confidence. Table 4 shows the results of this test. It can be observed that significant differences $(p<0.01)$ have been found for cholest-5en-3 3,25-diol in fresh loin (showing a higher level in shelf-life). Cholestane-5 $\alpha, 6 \alpha$-epoxide also presents significant differences $(p<0.05)$. However, no compound shows significant differences in marinated loin. Nam et al. (2001) detected higher amounts of $7 \alpha$ - or $7 \beta$-hydroxycholesterol and total COPs in raw pork after 7 days of storage.

In Table 5, the results obtained from the MannWhitney $U$ test to study the effect of temperature are presented for both kinds of samples (fresh and marinated). Two temperatures $\left(4\right.$ and $\left.8{ }^{\circ} \mathrm{C}\right)$ have been applied for the storage. Only significant differences $(p<0.05)$ are observed for cholest-5-en-3 $\beta, 25$ diol in fresh loin. There are no references about the effect of temperature in COPs. In marinated loin, 
significant differences have not been found in any compound, possibly because of the additives used.

In addition, the effect of packaging atmosphere (air, modified atmosphere packaging (MAP) and vacuum) has been study applying a Kruskal-Wallis test. The results are in Table 6 and it can be deduced that there are significant differences $(p<0.05)$ between MAP and air for cholest-5-en-3 $\beta, 7 \beta$-diol in the case of fresh loin, with the mean value at its highest in air. This fact is in agreement with the expected result and with that observed by Nam et al. (2001). They found that aerobically packaged and irradiated meats had higher COP values (Nam et al., 2001). On the other hand, the packaging atmosphere has no effect on the COPs from marinated loin.

TABLE 4. Mann-Whitney U Test by variable time for both types of samples

\begin{tabular}{|c|c|c|c|c|c|c|}
\hline \multirow[b]{2}{*}{ COPs } & \multicolumn{3}{|c|}{ Fresh $(n=27)$} & \multicolumn{3}{|c|}{ Marinated $(n=27)$} \\
\hline & $\mathbf{U}$ & $\mathbf{Z}$ & p-level & $\mathbf{U}$ & $\mathbf{Z}$ & p-level \\
\hline 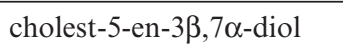 & 46.50000 & 1.77449 & - & 66.00000 & 0.77152 & - \\
\hline 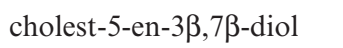 & 43.00000 & 1.95451 & - & 56.00000 & -1.28586 & - \\
\hline cholestane- $5 \beta, 6 \beta$-epoxide & 54.50000 & 1.36301 & - & 75.50000 & 0.28289 & - \\
\hline cholestane- $5 \alpha, 6 \alpha$-epoxide & 32.00000 & 2.52029 & $*$ & 58.00000 & -1.18299 & - \\
\hline cholestane- $3 \beta, 5 \alpha, 6 \beta$-triol & 70.00000 & 0.56578 & - & 69.00000 & -0.61721 & - \\
\hline cholest-5-en-3 $\beta, 25$-diol & 0.00000 & 4.16619 & $* *$ & 74.00000 & -0.36004 & - \\
\hline 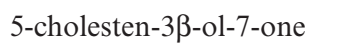 & 76.00000 & 0.25717 & - & 72.00000 & -0.46291 & - \\
\hline
\end{tabular}

*For $\mathrm{p}<0.05$ and $* *$ for $\mathrm{p}<0.001$.

TABLE 5. Mann-Whitney U Test by variable temperature for both types of samples

\begin{tabular}{|c|c|c|c|c|c|c|}
\hline \multirow[b]{2}{*}{ COPs } & \multirow{2}{*}{$\begin{array}{c}\text { Fresh }(n=27) \\
U\end{array}$} & \multicolumn{5}{|c|}{ Marinated $(n=27)$} \\
\hline & & $\mathbf{Z}$ & p-level & $\mathbf{U}$ & $\mathbf{Z}$ & p-level \\
\hline cholest-5-en-3$\beta, 7 \alpha$-diol & 46.50000 & 1.774489 & - & 62.00000 & -0.97725 & - \\
\hline cholest-5-en-3 $\beta, 7 \beta$-diol & 58.00000 & 1.182992 & - & 64.00000 & -0.87439 & - \\
\hline cholestane- $5 \beta, 6 \beta$-epoxide & 50.50000 & 1.568751 & - & 80.00000 & -0.05143 & - \\
\hline cholestane- $5 \alpha, 6 \alpha$-epoxide & 57.00000 & 1.234427 & - & 79.00000 & -0.10287 & - \\
\hline cholestane- $3 \beta, 5 \alpha, 6 \beta$-triol & 77.00000 & -0.205738 & - & 46.00000 & -1.80021 & - \\
\hline cholest-5-en-3 $\beta, 25$-diol & 36.00000 & 2.314550 & $*$ & 58.00000 & -1.18299 & - \\
\hline 5-cholesten-3 $\beta$-ol-7-one & 81.00000 & 0.000000 & - & 68.00000 & -0.66865 & - \\
\hline
\end{tabular}

*For $\mathrm{p}<0.05$.

TABLE 6. Significant differences within both types of samples (fresh and marinated) for the COPs analyzed according to the different packaging atmosphere (air, MAP and vacuum)

\begin{tabular}{|c|c|c|c|c|c|c|c|c|}
\hline \multirow[b]{2}{*}{ COPs } & \multicolumn{4}{|c|}{ Fresh $(n=27)$} & \multicolumn{4}{|c|}{ Marinated $(n=27)$} \\
\hline & $\mathbf{H}$ & $\mathbf{A} / \mathbf{V}$ & A/MAP & V/MAP & $\mathbf{H}$ & $\mathrm{A} / \mathrm{V}$ & A/MAP & V/MAP \\
\hline cholest-5-en-3 $\beta, 7 \alpha$-diol & 0.41 & ns & $\mathrm{ns}$ & $\mathrm{ns}$ & 0.90 & ns & $\mathrm{ns}$ & $\mathrm{ns}$ \\
\hline cholest-5-en-3 $\beta, 7 \beta$-diol & 6.40 & ns & $*$ & $\mathrm{~ns}$ & 0.17 & ns & $\mathrm{ns}$ & ns \\
\hline cholestane- $5 \beta, 6 \beta$-epoxide & 1.40 & ns & $\mathrm{ns}$ & $\mathrm{ns}$ & 0.91 & ns & $\mathrm{ns}$ & ns \\
\hline cholestane- $5 \alpha, 6 \alpha$-epoxide & 3.24 & $\mathrm{~ns}$ & $\mathrm{~ns}$ & $\mathrm{~ns}$ & 0.47 & ns & $\mathrm{ns}$ & ns \\
\hline cholestane-3 $3,5 \alpha, 6 \beta$-triol & 1.01 & ns & ns & $\mathrm{ns}$ & 2.89 & ns & $\mathrm{ns}$ & ns \\
\hline cholest-5-en-3 $\beta, 25$-diol & 0.74 & ns & $\mathrm{ns}$ & $\mathrm{ns}$ & 2.41 & ns & $\mathrm{ns}$ & ns \\
\hline 5-cholesten-3ß-ol-7-one & 0.99 & ns & ns & ns & 0.52 & ns & ns & ns \\
\hline
\end{tabular}

ns, not significant; * for $\mathrm{p}<0.05$; air: A; vacuum: V. Comparison between packaging atmospheres using Kruskal-Wallis Test. 
TABLE 7. Significant differences within both types of samples for the COPs analyzed according to the different irradiation doses $(0,1$ and $2 \mathrm{kGy})$

\begin{tabular}{|c|c|c|c|c|c|c|c|c|}
\hline \multirow[b]{2}{*}{ COPs } & \multicolumn{4}{|c|}{$\operatorname{Fresh}(n=27)$} & \multicolumn{4}{|c|}{ Marinated $(n=27)$} \\
\hline & $\mathbf{H}$ & $0 / 1$ & $0 / 2$ & $1 / 2$ & $\mathbf{H}$ & $0 / 1$ & $0 / 2$ & $1 / 2$ \\
\hline cholest-5-en-3 $\beta, 7 \alpha$-diol & 2.08 & ns & $\mathrm{ns}$ & ns & 2.14 & ns & ns & ns \\
\hline cholest-5-en-3 $\beta, 7 \beta$-diol & 0.79 & $\mathrm{~ns}$ & $\mathrm{~ns}$ & ns & 0.14 & ns & $\mathrm{ns}$ & ns \\
\hline cholestane- $5 \beta, 6 \beta$-epoxide & 0.87 & $\mathrm{~ns}$ & $\mathrm{~ns}$ & ns & 1.53 & $\mathrm{~ns}$ & $\mathrm{~ns}$ & ns \\
\hline cholestane- $5 \alpha, 6 \alpha$-epoxide & 0.23 & $\mathrm{~ns}$ & $\mathrm{~ns}$ & $\mathrm{~ns}$ & 0.46 & $\mathrm{~ns}$ & $\mathrm{~ns}$ & ns \\
\hline cholestane- $3 \beta, 5 \alpha, 6 \beta$-triol & 1.82 & ns & $\mathrm{ns}$ & ns & 0.24 & ns & $\mathrm{ns}$ & ns \\
\hline cholest-5-en-3 $\beta, 25$-diol & 0.29 & $\mathrm{~ns}$ & $\mathrm{~ns}$ & ns & 5.72 & ns & $\mathrm{ns}$ & ns \\
\hline 5-cholesten-3 $\beta$-ol-7-one & 1.34 & ns & ns & ns & 2.23 & ns & ns & ns \\
\hline
\end{tabular}

ns, not significant. Comparison between irradiation doses using Kruskal-Wallis Test.

Finally, several irradiation doses have been used for both types of loin ( 0,1 and $2 \mathrm{kGy})$. The effect of this was also studied using a Kruskal-Wallis test, whose data are presented in Table 7. No effect of the irradiation doses (up to $2 \mathrm{kGy}$ ) on the changes in the individual COPs in fresh and marinated loin was observed, which is a valuable result since E-beam may be applied as a useful tool for extending the shelf-life of fresh or marinated loin without alterations. In previous studies (Nam et al., 2001), the irradiated meats showed higher amounts of COPs which is opposite to the results found in the present study, but it can be due to the fat that the doses were higher (4.5 KGy).

\section{CONCLUSIONS}

A study of the effect of E-beam irradiation and packaging on COPs from fresh and marinated pork loin was carried out. An inhibitory effect in the formation of COPs was observed when a marinade was used. The amount and composition of cholesterol oxidation products in fresh loin varied depending on storage temperature, packaging atmosphere and storage time. However, minor changes were observed in marinated loin with storage time alone. Irradiation (bellow $2 \mathrm{KGy}$ ) did not have any effect on COP composition.

\section{ACKNOWLEDGMENTS}

The authors are grateful to Prof. J.A. Ordoñez for his help and advising. This study was supported by projects P08-AGR-03498, AGL-200765235-C02-02 and CSD 2007-00016 of the program CONSOLIDER INGENIO 2010.

\section{REFERENCES}

Ahn DU, Olson DG, Jo C, Chen X, Wu C, Lee JI. 1998. Effect of muscle type, packaging, and irradiation on lipid oxidation, volatile production, and color in raw pork patties. Meat Sci. 49, 27-39. http://dx.doi.org/10.1016/ S0309-1740(97)00101-0.
Anónimo. 2000. USDA approves red meat irradiation. Meat Processing March/April, p. 11.

Derewiaka D, Obiedzin'ski M. 2010. Cholesterol oxides content in selected animal products determined by GC-MS. Eur. J. Lipid Sci. Technol. 112, 1130-1137. http://dx.doi. org/10.1002/ejlt.200900238

Dionisi F, Golay PA, Aeschlimann JM, Fay LB. 1998. Determination of cholesterol oxidation products in milk powders: Methods comparison and validation. J. Agric. Food Chem. 46, 2227-2233. http://dx.doi.org/10.1021/jf9710600.

Folch J, Lees M, Stanley GHS. 1957. A simple method for the isolation and purification of total lipids from animal tissues. J. Biol. Chem. 226, 497-509.

Food and Agriculture Organization of the United Nations (FAOST). 2004. Guía de mejores Técnicas Disponibles (MTDs) del sector porcino. Ministerio de Agricultura Pesca y Alimentación (MAPA), Unión europea, Fondo Estructural.

García-Márquez I, Narváez-Rivas M, Gallardo E, Cabeza CM, León-Camacho M. 2013a. Changes in the phospholipid fraction of intramuscular fat from pork loin (fresh and marinated) with different irradiation and packaging during storage. Grasas Aceites 64, 7-14. http://dx.doi. org/10.3989/gya.084312.

García-Márquez I, Narváez-Rivas M, Gallardo E, Cabeza CM, León-Camacho M. 2013b. Changes in the volatile compounds of pork loin (fresh and marinated) with different irradiation and packaging during storage. Grasas Aceites 64, 250-263. http://dx.doi.org/10.3989/gya.131412.

Guardiola F, Codony R, Addis PB, Refecas M, Boatella J. 1996. Biological effects of oxysterols: Current status. Food Chem. Toxicol. 2, 193-211. http://dx.doi.org/10.1016/02786915(95)00094-1.

Guía de mejores Técnicas Disponibles (MTDs) del sector porcino. Ministerio de Agricultura Pesca y Alimentación (MAPA), Unión europea, Fondo Estructural. 2006.

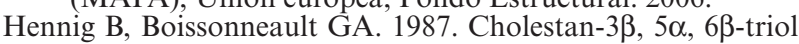
decrease barrier function of cultured endothelial cell monolayers. Atherosclerosis 68, 255-261. http://dx.doi.org/ 10.1016/0021-9150(87)90205-X.

Hwang KT, Maerker G. 1993. Quantitation of Cholesterol Oxidation Products in Unirradiated and Irradiated Meats Eastern Regional Research Center, J. Am. Oil Chem. Soc. 70, no. 4. U.S. Department of Agriculture, ARS, Philadelphia, Pennsylvania. http://dx.doi.org/10.1007/BF02552709.

IFT. 1999. Facts on food irradiation featured by the IFT New York Section. Food Technol. 53, 94-95.

Janoszca B. 2010. 7-Ketocholesterol and 7-hydroxycholesterol in pork meat and its gravy thermally treated without additives and in the presence of onion and garlic. Meat Sci. 86, 976-984. http://dx.doi.org/10.1016/j.meatsci.2010.08.003.

Kubow S. 1990. Toxicity of dietary lipid peroxidation products. Trends Food Sci. Technol. 1, 67-74. http://dx.doi. org/10.1016/0924-2244(90)90049-5. 
Lebovics VK, Gaal O, Somogyi L, Farkas J. 1992. Cholesterol oxides in $\gamma$-irradiated spray-dried egg powder. J. Sci. Food Agric. 60, 251-254. http://dx.doi.org/10.1002/jsfa.2740600214.

Lee HW, Chien JT, Chen BH. 2008. Inhibition of cholesterol oxidation in marinated foods as affected by antioxidants during heating. Food Chem. 108, 234-244. http://dx.doi. org/10.1016/j.foodchem.2007.10.072.

Leonarduzzi G, Sottero B, Poli G. 2002. Oxidized products of cholesterol: dietary and metabolic origin, and proatherosclerotic effects (review). J. Nut. Biochem. 13, 700-710. http://dx.doi.org/10.1016/S0955-2863(02)00222-X.

Lund E, Bjorkhem I. 1994. Down-regulation of hepatic HMGCoA reductase in mice by dietary cholesterol: importance of the 5 double bond and evidence that oxidation at C-3, C-5, C-6 or C-7 is not involved. Biochem. 33, 291-297. http://dx.doi.org/10.1021/bi00167a038.

Nam KC, Du M, Jo C, Ahn DU. 2001. Cholesterol oxidation products in irradiated raw meat with different packaging and storage time. Meat Sci. 58, 431-435. http://dx.doi. org/10.1016/S0309-1740(01)00046-8.

Narváez-Rivas M, Pham AJ, Schilling MW, León-Camacho M. 2014. A new SPE/GC-fid method for the determination of cholesterol oxidation products. Application to subcutaneous fat from Iberian dry-cured ham. Talanta 122, 58-62. http://dx.doi.org/10.1016/j.talanta.2014.01.040.

Paniangvait P, King AJ, Jones AD, German BG. 1995. Cholesterol oxides in foods of animal origin. J. Food Sci. 60, 1159-1174. http://dx.doi.org/10.1111/j.1365-2621.1995.tb04548.x.

Park SW, Addis PB. 1985. HPLC Determination of C-7 Oxidized Cholesterol Derivatives in Foods. J. Food Sci. 50, 1437-1441. http://dx.doi.org/10.1111/j.1365-2621.1985.tb10494.x.
Penzzi G, Carboni MF, Zunin P, Evangelisti F, Tiscornia R, Gallina Toschi T, Lercker G. 1995. Routine higy-performance chromatographic determination of free 7-ketocholesterol in some foods by two different analytical methods. J. Am. Oil Chem. Soc. 72, 1523-1527. http:// dx.doi.org/10.1007/BF02577847.

Peng SK, Taylor CB, Hill JC, Morin RJ. 1985. Cholesterol oxidation derivatives and arterial endothelial damage. Atherosclerosis 54, 121-133. http://dx.doi.org/10.1016/ 0021-9150(85)90172-8.

Savage GP, Dutta PC, Rodríguez-Estrada MT. 2002. Cholesterol oxides: their occurrence and methods to prevent their generation in foods. J. Clin. Nut. 11, 72-78.

Sevanian A, Peterson AR. 1986. The cytotoxic and mutagenic properties of cholesterol oxidation products. Food Chem. Toxicol. 24, 1103-1109. http://dx.doi.org/10.1016/ 0278-6915(86)90295-4.

Smith LL. 1980. The Autoxidation of Cholesterol, in Simic MG and Karel M (Eds.) Autoxidation in Food and Biological Systems, Plenum Press, New York and London, pp. 119132. http://dx.doi.org/10.1007/978-1-4757-9351-2_7.

Ubhayasekera SJKA. 2009. Sterols and Oxysterols: occurrence and analysis in by-product feed fats and animal tissues. PhD Thesis, Swedish University of Agricultural Sciences, Uppsala, Sweden.

Ubhayasekera SJKA, Verleyen T, Dutta PC. 2004. Analytical, Nutritional and Clinical Methods Evaluation of GC and GC-MS methods for the analysis of cholesterol oxidation products. Food Chem. 84, 149-157. http://dx.doi. org/10.1016/S0308-8146(03)00259-0. 